\title{
Violência urbana no documentário contemporâneo brasileiro: uma questão de diferença e poder
}

\author{
Gustavo Souza1 \\ ECO/UFRJ \\ gustavoo3@uol.com.br
}

\begin{abstract}
Resumo: Este trabalho quer investigar os fatores que possibilitam a recorrente presença dos segmentos socialmente marginalizados na produção de documentários brasileiros após 1993 ou da "retomada". Nosso enfoque concentra-se nos documentários que apresentam como personagens pessoas ou grupos diretamente vinculados ao contexto de violência urbana. Partimos do pressuposto que a visibilidade conquistada por esses setores relaciona-se, de uma forma ou de outra, às demarcações da "diferença" e às estruturas de poder. Para tanto, tomaremos como referência a leitura do conceito de différance, de Jacques Derrida, empreendida por Stuart Hall e os estudos sobre formações e estruturas de poder realizados por Michel Foucault e Gilles Deleuze.
\end{abstract}

Palavras-chaves: documentário, violência urbana, diferença, poder.

\begin{abstract}
This paper is aimed at investigating the relationship between national production of documentaries and socially marginalized groups. It is chronologically circumscribed in the late 90 's, when the national cinema undertook a "resurgence". Our approach is concentrated in the sets of documentaries that present as personages people or groups directly tied with the context of urban violence. We leave of the estimated one the visibility conquered for these sectors becomes related, of one it forms or another one, through demarcates of the "difference" and through structures of power. We will take as reference the reading of the concept of différance, by Jacqeus Derrida, undertaken by Stuart Hall, and studies on formations and structures of power carried through Michel Foucault and Gilles Deleuze.
\end{abstract}

Key words: documentary, urban violence, difference, power. 
Résumé: Ce travail veut faire une recherche sur les facteurs qui rendent possible la présence courante des segments socialement marginalisés dans la production de documentaires brésiliens aprés 1993. Notre approche se concentre sur les documentaires qui présentent comme personnages des personnes ou des groupes directement attachés au contexte de la violence urbaine. Nous avons parti de la présupposition de que la visibilité conquise par ces secteurs a des rapports, d'une façon ou d'autre, avec les bornes-limites de la "différence" et les structures de pouvoir. Pour cela, nous prendrons comme référence la lecture du concept de différance, de Jacques Derrida, entreprise par Stuart Hall et les études sur les formations et les structures de pouvoir réalisés par Michel Foucault et Gilles Deleuze.

Mots clefs: documentaire, violence urbaine, différence, pouvoir.

Resumen: Este trabajo pretende investigar los factores que posibilitan la permanente presencia de los segmentos socialmente marginalizados en la producción de los documentales brasileños después de 1993. Nuestro enfoque se concentra en los documentales que presentan como personajes personas o grupos directamente vinculados al contexto de violencia urbana. Partimos del presupuesto que la visibilidad conquistada por estes sectores se relaciona, de una o outra manera, a las demarcaciones de la "diferencia" y a las estructuras del poder. Para tanto, tomaremos como referencia la lectura del concepto de différance, de Jacques Derrida, emprendida por Stuart Hall y los estudios acerca de las formaciones y estructuras del poder realizadas por Michel Foucault y Gilles Deleuze.

Palabras llave: documentale, violencia urbana, diferencia, poder.

\section{Introdução}

A relação entre o cinema brasileiro e os segmentos considerados "marginais" existe desde os primeiros momentos da produção de filmes no país: surgiu de forma dispersa no período mudo, ganhou relevo nos filmes de Humberto Mauro, passou pelas comédias da Cinédia e da Atlântida, com seus malandros e vigaristas, até se intensificar em termos temáticos a partir dos anos 50 com os filmes de Nelson Pereira dos Santos e, em seguida, o cinema novo, que coroou o sertão e seus personagens como a representação máxima de um Brasil pouco preocupado com a distribuição de renda. Nota-se que, em suas diferentes materializações, a marginalidade tem sido um tema recorrente no cinema brasileiro. Se, nos anos 60, ficções e documentários enfocaram o sertão nordestino e todo tipo de 
adversidade nele presente, hoje, retirantes e flagelados cedem espaço para os setores socialmente marginalizados em um contexto urbano. Desse modo, a periferia urbana tem exercido um intenso fascínio entre diretores, que acabam se voltando para esse universo e seus personagens. Muito embora a temática do sertão tenha sido revisitada em filmes de ficção como Central do Brasil (Walter Salles, 1998), O Auto da Compadecida (Guel Arraes, 2000) e Eu, tu, eles (Andrucha Waddington, 2000).

Nesse sentido, o foco desse trabalho recai sobre os fatores que possibilitam a visibilidade de tais setores marginais na produção nacional de documentários pós-1993. A escolha pelo documentário se dá, inicialmente, por um recorte metodológico, pois abordar a amplitude da recente produção fílmica brasileira tornaria o trabalho inviável para este momento. Essa "invasão" não se restringe apenas à produção de documentário, mas também a filmes de ficção e videoclipes. Mas é preciso reconhecer que esses formatos, embora tratem do mesmo contexto, obedecem a matrizes que instituem diferentes processos de representação. Em segundo lugar, destaca-se o fato de o cinema brasileiro atual mostrar-se dividido entre a vontade de integrar-se ao mainstream ou, então, refutar esse caminho em busca de um diferencial e de sua "voz própria". O documentário parece situar-se nesse segundo "grupo".

Para nos ajudar no entendimento da questão, selecionamos dois documentários realizados a partir da segunda metade dos anos 90. São eles: Notícias de uma guerra particular (João Moreira Salles e Kátia Lund, 1998) e O rap do pequeno principe contra as almas sebosas (Paulo Caldas e Marcelo Luna, 2000). Notícias... aborda a questão do tráfico de drogas no Rio de Janeiro. Para isso, ouve os envolvidos diretamente na guerra travada nos morros cariocas entre traficantes e policiais. No meio do fogo cruzado, encontra-se o morador. Já O rap do pequeno príncipe... contrapõe as vivências de Hélio e Garnizé, nascidos e criados em Camaragibe (município pobre da Região Metropolitana do Recife). Hélio se torna justiceiro, cujo "trabalho" é eliminar estupradores, assaltantes e delinqüentes da

\footnotetext{
${ }^{1}$ Ele não é composto apenas por documentários, mas também por filmes de ficção que também procuram refletir de forma menos palatável o contexto de marginalidade e violência urbana, como ocorre em O invasor (Beto Brant, 2001) ou Como nascem os anjos (Murilo Salles, 1996).
} 
convivência dos moradores do bairro onde mora. Garnizé, por sua vez, responde à violência com música e trabalhos sociais, atuando também na comunidade onde vive.

\section{Uma questão de diferenças}

A discussão em torno da marginalidade nos conduz a verificar estruturas e implicações relacionadas ao contexto de violência urbana. Vivemos hoje num estado de alerta constante, em que ninguém parece escapar dos efeitos da violência. Mas, sem dúvida, são as classes menos assistidas pelos aparelhos estatais que sofrem mais diretamente as conseqüências desse fenômeno. Nosso olhar, portanto, direciona-se para esses setores. Mas é preciso frisar desde já: não se corrobora aqui a premissa segundo a qual a pobreza é responsável pela violência, isto é, como se os pobres tivessem impresso em seus genes uma característica que os tornam aptos a organizar e manter a violência urbana. Parece que vivemos nos tempos de um neo-darwinismo social em que a violência urbana é usada como uma marca instintiva que distingue e classifica pessoas.

A imagem imediata que formulamos quando o assunto é violência urbana talvez surja das nossas próprias experiências nesse ensejo ou aquelas já consagradas pelos meios de comunicação de massa: o jovem com a arma na mão - seja para o assalto à mão armada, a proteção da boca de fumo ou o confronto com a polícia. Antes de associar a violência urbana a essas situações mais imediatas, é preciso ter em mente os fatores que promovem sua constituição. A conjuntura em que a sociedade brasileira se encontra hoje não surge a partir do jovem de posse de uma arma. Essa imagem é apenas o ponto final de um percurso no qual a sociedade brasileira já trilha há bastante tempo. Percurso apresentado por Régis de Morais, em obra introdutória sobre o assunto, no início dos anos 80, e que antecipou muitas das questões que hoje integram as discussões em torno da violência urbana como, por exemplo: fracassos familiares; descrenças nas experiências pessoais e coletivas; burocratização ou desaquecimento das relações humanas; o descompasso na concretização de desejos revelando questões de poder e hierarquias (cf. Morais, 1981).

A violência urbana surge, então, no bojo de uma série de fatores que colocam o pesquisador face a questionamentos sobre que método adotar diante desse fenômeno para quem se evitem posicionamentos fossilizados. A tarefa, como reconhece Glória Diógenes, 
não é das mais simples. Em suas pesquisas sobre gangues, galeras e o movimento hip-hop, a autora considera que o estudo sobre o tema deve considerar uma série de elementos que se conectam entre si: ordem, caos, incerteza, acaso, fragmentação, imprevisibilidade, diferenças, instabilidade. Esse arcabouço permite ultrapassarmos as categorizações dualistas do tipo "bem" ou "mal" para entendermos a complexidade que cerca e constitui o comportamento social violento. Por essa razão, a autora frisa que é importante "perceber uma teia de acontecimentos que se constroem no campo 'desconhecido' e 'maldito' da violência e qual sua 'eficácia' nas redes de sociabilidade dos atores que a praticam" (Diógenes, 1998, p. 90).

Os documentários mostram que o tráfico nos morros cariocas e as ações dos justiceiros na periferia do Recife extrapolam o âmbito da favela. Toda sociedade experimenta a particularização de experiências restritas a certos segmentos, categorias e até indivíduos, mas também vivencia a universalização de outras, que expressam o sentimento de unidade. Uma ação localizada, sejam seus efeitos maléficos ou benéficos, pode desconstruir barreiras geográficas e aproximar diferentes estratos sociais. Dessa forma, quando a periferia começa a perturbar - por meio da violência urbana - as instâncias de poder, traz consigo não apenas o medo e a insegurança, mas também sua auto-projeção. É essa conjuntura na produção brasileira de documentários que pretendemos entender.

As assimetrias de uma sociedade permitem o estabelecimento de diferenças entre os seus integrantes. Aqueles que pensam e agem de forma diferenciada de um determinado grupo definirão as reais fronteiras que separam os indivíduos. Dessa forma, o "diferente" atende às necessidades de uma determinada comunidade e, ao mesmo tempo, submetem essa comunidade às suas regras. Um dos tópicos abordados em Notícias de uma guerra particular diz respeito às ações do tráfico e seus efeitos sobre o morro ou favela onde se instala. Como evidenciam os depoimentos dos moradores, com o tráfico, instaura-se uma nova ordem social baseada em códigos e leis ditadas diretamente por quem comanda a vendagem de drogas. Ao morador não resta opção, a não ser seguir as "orientações" de conduta. Seus comandantes, entretanto, estão cientes de que o uso da força não pode ser uma constante. Por isso, suprem as necessidades emergenciais dos moradores. Cria-se, assim, entre o morador e o tráfico, um pacto balizado no assistencialismo. O morador, por 
sua vez, entende que tal prática não se dá ao acaso e, mesmo a contragosto, estabelece uma espécie de pacto com o "movimento". Como relata a moradora Janete:

O tráfico de um lado melhorou e de outro não. Porque antes de existir o tráfico a polícia quando entrava na favela, ela já entrava metendo o pé na porta da sua casa e já vinha quebrando tudo. Então essas arma quando entraram na comunidade através do tóxico, fez com que eles entrasse com mais cautela, entendeu. (...). Agora o lado negativo, (...) é que quando eles têm que cobrar, seja de pessoa lá de baixo, seja da nossa comunidade, (...) eles não querem saber se é menor, se não é, entendeu. Se eles puderem matar, esquartejar e cortar e colocar lá pra todo mundo ver como exemplo, pra ninguém vacilar, porque senão vai pra vala, eles são capazes disso.

A urgência na resolução de necessidades individuais não pode esperar pelo encurtamento do hiato que separa as comunidades não assistidas e os aparelhos estatais. É através do imediatismo que traficantes estabelecem a malha que os qualificam no bojo das relações sociais, tanto em relação à sua comunidade como às outras "de fora". Dessa maneira, percebemos que as instâncias minoritárias podem interferir e moldar a forma de agir dos setores majoritários. A idéia de que os órgãos governamentais deveriam viabilizar as necessidades básicas do cidadão é posta de lado e, ao invés de se esperar por eles, partese para a prática. No caso do tráfico, a ação, mesmo assistencialista, tem um caráter coletivo, como mostra o depoimento anterior.

Por outro lado, há também as práticas de caráter individual, que não esperam as ações estatais, como pode ser visto em $O$ rap do pequeno príncipe... A iniciativa do justiceiro Helinho nos direciona novamente ao fato de o minoritário perturbar as instâncias majoritárias. Para não perder a proteção do justiceiro, a comunidade onde ele atuava se articula para pedir à justiça sua liberdade, uma vez que é visto como um benfeitor. Como mostra o documentário, um carro de som circula pelo bairro pedindo aos moradores que assinem um "abaixo-assinado” pela liberdade do justiceiro Hélio.

Os documentários em questão reforçam ainda situações já conhecidas do grande público, mas que não deixam de chamar a atenção para as conseqüências decorrentes desse locus particular. Os filmes retratam populações inseridas num contexto de pobreza, miséria e violência urbana. A possibilidade de conseguir dinheiro e status em curto prazo leva muitos jovens a ingressarem na "empresa" que é o tráfico de drogas, como destaca Hélio 
Luz, ex-chefe da Polícia Civil, em depoimento a Notícias de uma guerra particular. O conflito e a tensão social decorrente do tráfico funcionam muito mais como um atrativo do que como uma repulsa para crianças e adolescentes que procuram ingressar na carreira do narcotráfico. No caso do justiceiro Helinho, de $O$ rap do pequeno príncipe..., a situação não é muito divergente. As condições adversas de sobrevivência pelas quais ele passou facilitaram o seu envolvimento com a criminalidade, o que, por um lado, lhe trouxe problemas com a justiça e, por outro, tornou-o um ídolo perante a comunidade onde atuava. Nesse sentido, não se pode deixar de mencionar o poder de alcance dos meios de comunicação, que, através da disseminação da informação em "massa", é capaz de tornar as ações de um "fora da lei" um exemplo a ser seguido.

Em meio aos processos homogeneizantes decorrentes da globalização, assistimos à intensificação das experiências localizadas, e além disso, o reforço das diferenças indispensável para a engrenagem de qualquer sociedade. Dentro desse contexto, Stuart Hall vai falar sobre a proliferação subalterna da diferença. Uma instância que rompe com binarismos iluministas, como tradicionalismo X modernidade, ao postular a emergência de diversas modernidades localizadas que na globalização intensificam a disputa entre os interesses locais e globais, ainda longe de uma convergência harmônica. Hall utiliza o conceito de différance, de Jacques Derrida, para entender como essas negociações circunscrevem-se na nova conjuntura sociocultural arquitetada a partir de tensões e diálogos entre esses dois pólos. Para o autor, a différance, originalmente elaborada no âmbito da produção de linguagem, expõe as implicações dos processos globalizantes, por simultaneamente marcar diferenças e diferir, suspender, adiar, desviar (cf. Hall, 2003, p. 92). Isso permite que as práticas sociais possam ser vistas para além dos binarismos que demarcam espaços, classificam, excluem ou incluem. O jogo da différance permite que os significados desconstruam qualquer rigidez limitadora. A saturação das totalidades deve, portanto, ser posta de lado. A perspectiva de Derrida não se limita ao esquema nós $\mathrm{x}$ outros, mas opera dentro de uma lógica que concebe qualquer sistema de forma oscilante, movediço e heterogêneo. "Filosoficamente, a lógica da diferença significa que o significado/identidade de cada conceito é constituído em relação a todos os demais conceitos do sistema em cujos termos ele significa"( Ibid., p. 85). 
A instabilidade referente à différance contribui para a emergência de novos localismos. Não se trata de um processo auto-suficiente, nem de um mero simulacro do global. Para Hall, esse movimento favorece o “'retorno' do particular e do específico - do especificamente diferente - no centro da aspiração universalista panóptica da globalização ao fechamento" (Ibid., p, 61.). Essa condição é a marca das relações socioculturais da atualidade, uma vez que suspendem, adiam, protelam qualquer possibilidade de definição fixa do global em relação ao local, ou nos dizeres de Hall, constituem "o momento de descentramento incerto, lento e prolongado do Ocidente" (Ibid., p, 61.).

O jogo das diferenças, inevitavelmente, chega aos produtos culturais. Como uma arte que absorve ressonâncias, assimetrias e valorações da sociedade, o cinema não se ausenta da abordagem de temas que, de certa forma, confirmem o espaço da diferença entre diversos setores sociais, ou, para ser mais específico, o universo do documentarista e do seu depoente. Dessa forma, o estado de alerta que mostra Notícias... não deixa de se confirmar como uma forma de "diferenciação", mesmo que traga prejuízos de toda ordem.

Se essa engrenagem "localizada" confirma sua presença por meio das ações decorrentes do tráfico, e saber sobre ela - transcendendo o campo descritivo - torna-se imprescindível. Movimento semelhante acontece em $O$ rap do pequeno príncipe.... A perplexidade que a princípio pode surgir diante de uma pessoa que matou 44 pessoas cede espaço para, a seguir, verificarmos possíveis motivos que impulsionaram esse modo de agir. Motivos que certamente não se limitam unicamente a uma questão pessoal, mas também como o reflexo de uma conjuntura social cujas políticas públicas faliram há tempos. Por outro lado, diante de uma situação tão desfavorável, o trabalho realizado pelo músico Garnizé também não deixa de ser um fator de diferenciação. Antes de prosseguirmos, uma ressalva: é preciso se furtar à tentação de considerar différance como sinônimo de diferença. O conceito de Derrida, em seu movimento de suspender, adiar e colocar em aberto, facilita a compreensão de como se articulam as diferenças num dado contexto social ou cultural. A compreensão da diferença torna-se mais acessível e completa com a intervenção da différance. Diferença e différance, portanto, podem ser articuladas como integrantes de um sistema de significações e sentidos, mas nunca como sinônimos. 


\section{Visibilidade: uma questão de poder}

O interesse pelos localismos, associado às questões de diferença, é um importante fator para entendermos a presença dos setores diretamente vinculados à violência urbana na produção brasileira de documentários. Traficantes e justiceiros, assim como assaltantes, presidiários ou travestis, despertam a atenção também pelas peculiaridades que carregam: a maneira como lidam com a violência, sua visão de mundo e seu estilo de vida, torna-os “objetos" de interesse, desejo e consumo. Reconhecer essa dimensão ajuda a entender a questão, mas apenas parcialmente.

A presença constante dos grupos subalternos na produção de documentários se dá porque manter o foco no marginal faz com que apenas esse segmento represente a sociedade brasileira como um todo. Transfere-se o "entendimento" de conjunturas e situações a apenas um setor, sem que as estruturas de poder também se façam presente, e dessa forma, contribuam para a discussão que se pretende instituir. Enquanto há avanços no quesito estético, quase não há alteração, em termos temáticos, em relação à classe. Dessa forma, o debate sobre a atuação e o papel de outros setores sociais é desperdiçado, ficando ausente da produção de documentários. Este ocultamento delega apenas a alguns personagens a tarefa que cabe a todos os segmentos: fornecer pistas para a compreensão de como funcionam os matizes sociais, culturais, políticos, religiosos e econômicos que integram o escopo social brasileiro. Mesmo que esse entendimento não seja completo, fazse necessário que um número máximo de grupos participem desse "projeto”. Na prática, sabemos que o periférico, em termos de notoriedade, é o alvo de documentaristas, e nessa direção, a visibilidade, como veremos adiante, está diretamente vinculada às forças que integram as redes poder.

A referência às "estruturas de poder" pede inevitavelmente uma definição do que entendemos por essa noção. Sabemos, de início, que tal definição é complexa e envolve uma série de posturas e questionamentos que variam de acordo com o referencial adotado. Deleuze, em seu livro sobre a obra de Michel Foucault, anuncia o caráter descontínuo e multifacetado do poder, que seria, em linhas gerais, constituído por "uma relação de forças" (Deleuze, 1986, p. 78). Foucault não escreveu sobre documentários, mas seu 
posicionamento sobre a estruturação do poder, quando aproximado da discussão sobre a visibilidade de um determinado segmento na produção audiovisual brasileira, contribui substancialmente para o debate.

Deleuze esclarece que o poder, segundo Foucault, são forças que agem de diversos pontos, de forma centrífuga e múltipla, impossíveis de serem decalcadas e capazes de estabelecer conexões e rupturas. A essa definição, Deleuze salienta três aspectos destacados por Foucault que ajudam no entendimento das relações de forças. A que nos interessa diretamente diz respeito ao fato de o poder atravessar tanto a esfera dos dominantes como dos dominados.3 Esse emaranhado nos conduz a uma problemática: a localização desse poder. Se defini-lo é aparentemente mais "simples", saber onde ele se situa é, no entanto, uma tarefa mais complexa. O próprio Foucault (1979, p. 75) reconhece tal dificuldade:

A teoria do Estado, a análise tradicional dos aparelhos de Estado sem dúvida não esgotam o campo de exercício e de funcionamento do poder. Existe atualmente um grande desconhecido: quem exerce o poder? Onde o exercer? Atualmente se sabe, mais ou menos, quem explora, para onde vai o lucro, por que mãos ele passa e onde ele se reinveste, mas o poder... Sabe-se muito bem que não são os governantes que o detêm. Mas a noção de "classe dirigente" nem é muito clara nem muito elaborada. "Dominar", "dirigir", "governar", "grupo de poder", "aparelho de Estado", etc.. é todo um conjunto de noções que exige análise.

A definição de poder inicialmente apontada - relação de forças justapostas e heterogêneas - ajuda também a reconhecer a dificuldade de delimitação. A ausência de uma forma específica para as estruturas de poder torna abrangente as esferas onde ele se materializa. Se em sua constituição prevalece o caráter fluído e polivalente, é pouco provável, por extensão, que uma delimitação tácita de seus matizes seja possível. A perspectiva foucaultiana reconhece que o poder não se materializa apenas no Estado, mas vai além. Ele pode ganhar forma em rituais, pessoas, crenças ou instituições. As relações de forças não implicam sempre que sejam coercitivas e unilaterais. Ao contrário, o poder é uma instância de controle e dominação, mas também de resistência. A multiplicidade que o

\footnotetext{
${ }^{3}$ Os outros dois postulados estabelecidos por Foucault dizem que o poder não é necessariamente repressivo, uma vez que incita, produz e suscita. $\mathrm{O}$ outro afirma que ele se exerce antes de se possuir. Mais detalhes, cf. Deleuze, Gilles, 1986, p. 79.
} 
constitui faz com que ele ultrapasse o âmbito de imposições e subordinações para se situar num espaço onde diferentes mecanismos atuam conjuntamente.

Entre as instâncias de poder passíveis de identificação destacam-se os meios de comunicação e a indústria cultural. A referência, embora inevitável, apresenta-se cabal para o nosso trabalho. O modo como os meios de comunicação de massa operam obedece a associações com outras esferas de poder como o Estado ou empresas privadas, preparando o terreno para outras importâncias que geralmente refletem o interesse de negociações e acordos previamente demarcados.

Nessa direção, a produção de documentários no Brasil parece também, num sentido diferente, materializar na imagem apenas uma parcela da população brasileira, que, embora numerosa, não tem condições de abarcar por completo a complexidade das diversas esferas que a compõe. Os media e os produtos culturais se apresentam como uma importante estrutura de poder e elaboram enunciados, sejam eles imagéticos, escritos ou falados, cujo enunciável (regime discursivo) e o visível (regime não-discursivo) formarão a base do que Foucault vai denominar como "saber". Assim, percebemos que Foucault estava correto ao afirmar que, embora guardem suas diferenças e especificidades, o poder só existe aliado ao saber.

Esse saber, na concepção foucaultiana, está balizado em dois pilares: o enunciável e o visível. ${ }^{4} \mathrm{O}$ entendimento dessas categorias, e posteriormente de suas articulações, deve ir além de seu sentido imediato, isto é, não se pode tomar o dizível apenas como a materialização de enunciados escritos ou falados, bem como o visível apenas do ponto de vista imagético. A imagem, por exemplo, tem o potencial tanto de enunciar como de tornar visível. Sobre essa questão, Deleuze destaca que a preocupação de Foucault com a enunciação o fez elaborar um esquema biunívoco que entrelaça o visível e o dizível nas malhas do saber. Foucault elaborou um regime que funciona pela negação: se o enunciável é visto como as formações discursivas, o visível será tomado como as formações não-

\footnotetext{
${ }^{4}$ Essas duas categorias apresentam uma série de sinônimos que passaremos a utilizar a partir de agora. Para evitarmos descontinuidades, devemos considerar os termos: legível, dizível, formação discursiva, formas de expressão como sinônimos de enunciável. Já o visível também pode ser denominado como formação não-discursiva ou formas de conteúdo.
} 
discursivas; se o legível é visto como uma forma de expressão, o visível será visto como uma forma de conteúdo (Deleuze, 1986, p. 41). Em trabalhos posteriores, como Vigiar e Punir, Foucault vai transcender as dualidades entre o visível e o dizível para elaborar uma terceira matriz para o saber. Dessa vez, abandona os esquemas duais para conceber o poder como um campo em que várias forças se entrecruzam sem um ponto de partida ou de chegada. Citando Foucualt, Deleuze (op. cit., p. 48) dirá que "não há relação de poder sem constituição correlata de um campo de saber, nem saber que não suponha e não constitua ao mesmo tempo relações de poder”. Para Deleuze, é um equivoco acreditar que o poder só se faz presente quando da suspensão do saber. Na verdade, são duas categorias que se encontram para formar um regime de significação cujo funcionamento se dará apenas a partir de uma convergência entre ambas.

Dessa forma, faz-se necessário atentar para as articulações entre o dizível e o visível. A tese de Foucault defende que os enunciados só são ditos em função das condições que lhes reservam, e que cada época elabora as condições necessárias para cada momento enunciativo. É o que ele vai definir como formação discursiva. Isso implica que os regimes discursivos determinam os não-discursivos, ou que o enunciável determina o visível. Em outras palavras, o que se pode ver vai depender do que se pode falar. Esta relação, contudo, não é estanque. O visível deixa-se determinar, mas sem se tornar mero joguete das formas de expressão. "Há apenas uma relação de forças que age transversalmente e que encontra na dualidade das formas a condição para a sua própria ação, para sua própria atualização. O enunciado só se justifica a partir da nova necessidade de que ele estabelece" (Ibid., p. 48.).

Assim, os enunciados se encontram com as visibilidades. A relação é, portanto, variável, pois os enunciados, bem como os sujeitos que os emitem, são instáveis, estão passíveis às influências externas e internas do seu tempo. A visibilidade, nesse sentido, não apresenta o mesmo local, nem o mesmo ritmo. Por essa razão Deleuze nos diz que "cada época diz tudo o que pode dizer em função de suas condições de enunciado" (Ibid). O autor postula também que as esferas de poder são igualmente mutáveis e variam de acordo 
com a época. ${ }^{5}$ Portanto, o caráter de multiplicidade rege tanto o saber, em seus componentes legíveis e visíveis, como o poder, em seus fluxos e contrafluxos de forças divergentes.

Aproximando esta discussão à produção brasileira de documentários, vemos que ao longo dos anos os enunciados, antes tidos como centrais, com o passar do tempo, foram cedendo espaço para outras formas enunciativas que, por extensão, produziram outras visibilidades. A observação é válida tanto em termos narrativos como temáticos. Nos anos 60 e 70, muitos documentários apostaram no modelo sociológico como estratégia narrativa. Tal modelo é um prova de como as visibilidades se articulam em torno do que se pode dizer. A VOz do narrador, como a vOz onipotente do saber, funcionava como um depositário de uma série de formas de expressão previamente traçadas que concedia a visibilidade a certos grupos sociais, mas uma visibilidade moldada de acordo com uma tese a ser confirmada. Dessa forma, o saber fica restrito apenas à figura do documentarista, que, através do narrador, institui uma relação de poder vertical a seus depoentes.

O documentário, como um produto cultural dotado de gradações e significados, também se apresenta como um espaço onde as relações de forças, os enunciados e as visibilidades dividem a mesma arena. No mesmo período em que o modelo sociológico vingava, em termos temáticos, predominava o sertão e seus assuntos correlatos. $\mathrm{O}$ sertanejo, o flagelado da seca e o migrante eram os personagens recorrentes da época. $\mathrm{O}$ processo de urbanização por qual passou o país nas últimas décadas, associado à falta de planejamento urbano e aos crescentes índices de violência urbana, fez com que os setores urbanos socialmente marginalizados passassem a obter mais visibilidade na produção de cinema no país, tanto na ficção como no documentário. Antes de prosseguirmos, é preciso uma ressalva: esse "deslocamento" do rural para o urbano não deve ser visto como efeito de uma suposta falência do modelo sociológico, ou seja, o reconhecimento das falhas de tal

\footnotetext{
${ }^{5}$ Não mudam somente os locais de materialização de poder, como até sua própria configuração, que passa de sociedade disciplinar para sociedade de controle. Mais informações sobre esse novo regime, ver "Post-scriptum sobre a sociedade de controle". Em: Deleuze, 1992, pp. 219-226.
} 
estratégia representacional conduz à abstração de seus temas recorrentes. Antes de associar o esquema sociológico com a temática, deve-se atentar que este constitui um modo de representação, que atende às estratégias enunciativas de seus realizadores ou dos grupos ou empresas os quais representa. É preciso frisar também tal "deslocamento" não deve ser tomado como definitivo, ou seja, a partir de agora assistimos apenas a filmes cujo cenário e seus personagens integram o ambiente urbano. ${ }^{6}$

Se os enunciados determinam os locais de visibilidade, resta saber como os personagens estão inseridos nessa teia formada por discurso e poder. O que o personagem apresenta de "diferente", sem dúvida, torna-se um atrativo. Afinal, o desconhecido sempre desperta algum tipo de reação, seja o distanciamento ou a aproximação. Freqüentemente classificado como outro (em itálico, sempre), o estranho tem sido, desde Flaherty, com Nanuk, o esquimó (1922), o grande "objeto de desejo" de documentaristas mundo afora. A presença desse outro no documentário é analisada por Nichols a partir da etnografia e da pornografia, que, a princípio tão distantes e desconexas, apresentam um ponto em comum: ambas podem ser vistas como uma rota de descobrimento de novas possibilidades das relações de poder. Buscamos em Nichols essa discussão para trazê-la à nossa a partir de quatro pontos específicos que o autor elabora. Dois deles nos interessam mais diretamente: um diz respeito ao estereótipo e o segundo, diretamente ligado ao primeiro, à dificuldade de lidar com a cultura alheia. ${ }^{7}$ O estereótipo ajuda a confirmar complexas formas de envolvimento emocional por parte do espectador. Já o segundo aspecto está estruturado em um sistema de oposição em que o outro não é visto como um produtor de significados, mas como um alienígena, em que é desprezada toda complexidade que o cerca.

Acreditamos que o outro nos ajuda a entender melhor a relação entre o documentarista e o personagem. Porém esse outro só existe como categoria analítica para

\footnotetext{
"O rural continua aparecendo na produção de cinema brasileiro como "locação" (Abril despedaçado, Walter Salles, 2001; Cinema, aspirinas e urubus, Marcelo Gomes, 2005) ou trazendo um tema cuja temática é específica do sertão (2000 Nordestes, Vicente Amorim e Davi França Neves, 2001; Árido movie, Lírio Ferreira, 2005).

${ }^{7}$ Os outros dois pontos destacados por Nichols versam sobre o pensamento humanista ocidental e sua tentativa de delegar categorias majoritárias entre as pessoas; a outra, baseada no pensamento de Laura Mulvey, defende a mulher como o principal "outro" da cultura ocidental. Mais informações, cf. Nichols,1991, pp. 207-208.
} 
delimitarmos espaços e ações, e dessa forma destrinchar pelo menos parte do emaranhado das relações de poder. O reconhecimento do que vem a ser o outro é fluido e sem baliza, pois essa noção muda de acordo com a perspectiva adotada. Se os ocidentais norteamericanos vêem os habitantes de uma remota aldeia na Papua Nova Guiné como outros, por não integrarem uma rede de tensões e significados na qual o habitante dos Estados Unidos está inserido, o inverso também pode acontecer, uma vez que os referenciais que moldam posicionamentos e identidades não são os mesmos para os habitantes da aldeia citada. Se o soldado do morro é visto como outro pela sociedade brasileira da qual ele não faz parte, os considerados "integrados" ou do "asfalto" também podem ser vistos como estranhos, diferentes, outros por seguirem certas regras de comportamento que, para o soldado, não fazem o menor sentido. De uma certa forma, todos nós, dependendo da ocasião, da localização e dos nossos posicionamentos, podemos nos tornar outro, o que conduz a uma homogeneização ou a um nivelamento dessa noção, ou, para utilizar a feliz definição de Rimbaud, "eu é um outro". A favela e seus personagens são temas apresentam há décadas uma continuidade no cinema brasileiro. Sua visibilidade muda em função das dinâmicas sociais e culturais que adquirem uma nova roupagem de acordo com a época. Esse aspecto, portanto, interfere diretamente na forma de ver e representar personagens e a realidade na qual eles estão inseridos.

\section{Referências bibliográficas}

DELEUZE, Gilles. Foucault. São Paulo: Brasiliense, 1986. . Conversações. Rio de Janeiro: Editora 34, 1992.

DIÓGENES, Glória. Cartografias da cultura e da violência: gangues, galeras e o movimento hip-hop. São Paulo: Annablume, 1998.

FOUCAULT, Michel. Microfísica do poder. 17. ed. São Paulo: Graal, 1979.

HALL, Stuart. Da diáspora: identidades e mediações culturais. Belo Horizonte: Editora UFMG, 2003.

MORAIS, Régis de. O que é violência urbana. São Paulo: Brasiliense, 1981.

NICHOLS, Bill. Representing reality. Bloomington: Indiana University Press, 1991. 